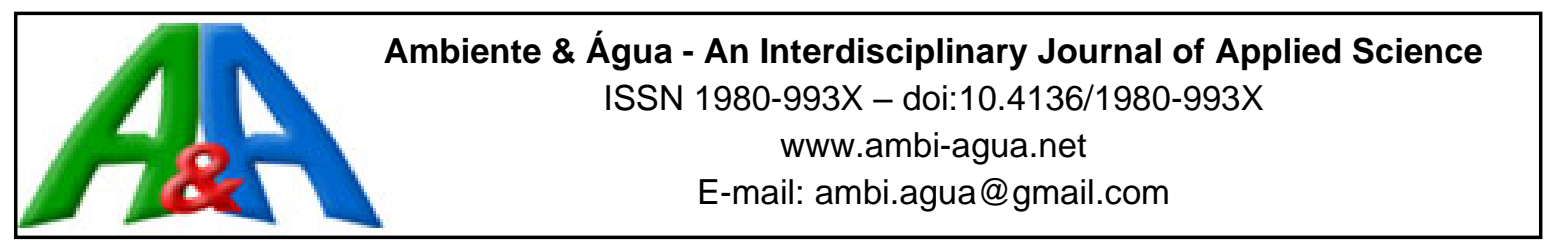

\title{
Evaluation of the environmental life cycle of an STP that employs a low-rate trickling filter as post-treatment of a UASB reactor and different sludge-management alternatives
}

\author{
ARTICLES doi:10.4136/ambi-agua.2648
}

Received: 14 Sep. 2020; Accepted: 19 Apr. 2021

\author{
Karina Guedes Cubas do Amaral*iD; Julio Cezar Rietow ${ }^{(D}$; Miguel Mansur Aisse \\ Departamento de Hidráulica e Saneamento (DHS). Universidade Federal do Paraná (UFPR), \\ Avenida Coronel Francisco Heráclito dos Santos, n 100, CEP: 81530-000, Curitiba, PR, Brazil. \\ E-mail: juliorietow@gmail.com, miguel.dhs@ufpr.br \\ *Corresponding author. E-mail: kacubas@gmail.com
}

\begin{abstract}
This study aimed to undertake an environmental life cycle assessment (LCA) of a sewage treatment plant (STP) equipped with low-rate trickling filters (TFs) as post-treatment of upflow anaerobic sludge blanket (UASB). The STP is located in South Brazil and uses landfill and agriculture as sludge-disposal alternatives. The evaluation was performed using the LCA technique and SimaPro® 9 software. The results revealed that the gases methane $\left(\mathrm{CH}_{4}\right)$ and sulfur dioxide $\left(\mathrm{SO}_{2}\right)$, emitted into the atmosphere after the partial burning of the biogas in flares, are mainly responsible for impacts in the categories of global warming (GW) and terrestrial acidification (TA), respectively. Due to the low rate of hydraulic sewage application in TFs, nitrous oxide $\left(\mathrm{N}_{2} \mathrm{O}\right)$ emissions stood out due to their high impact in the category of stratospheric ozone depletion (SOD). The use of sludge in agriculture obtained a greater potential for environmental impact compared to landfills in five of the eight categories evaluated. The main impacts of agricultural use were in the category of human toxicity (HT), due to the high concentration of zinc present in the sludge, and in the category TA, due to the emission of ammonia $\left(\mathrm{NH}_{3}\right)$ during hygienization of the sludge. In turn, the main positive aspects were avoided products, such as urea, phosphate fertilizer and limestone. The results contribute to a greater discussion of sewage-treatment processes, as well as sludge-management alternatives used in developing countries.
\end{abstract}

Keywords: alkaline stabilization, biogas, biological sludge, environmental assessment, nitrogen dioxide, sanitary landfill.

\section{Avaliação do ciclo de vida ambiental de uma ETE que emprega filtro biológico percolador, de baixa taxa, como pós-tratamento de um reator UASB e diferentes alternativas de gerenciamento de lodo}

\section{RESUMO}

O presente estudo teve por objetivo realizar a avaliação de ciclo de vida (ACV) ambiental de uma estação de tratamento de esgoto (ETE), dotada de filtros biológicos percoladores (FBPs) de baixa taxa, como pós-tratamento de reatores anaeróbios - UASB. A ETE está localizada no sul do Brasil e emprega como alternativas de destinação do lodo o aterro sanitário e o uso 
agrícola. Para realizar a avaliação, utilizou-se a técnica de ACV, empregando o software SimaPro® 9. Os resultados evidenciaram que os gases metano $\left(\mathrm{CH}_{4}\right)$ e dióxido de enxofre $\left(\mathrm{SO}_{2}\right)$, emitidos para a atmosfera, após a queima parcial do biogás em queimadores abertos, são os principais responsáveis pelos impactos nas categorias de mudanças climáticas (GW) e acidificação terrestre (TA), respectivamente. Devido à baixa taxa de aplicação hidráulica de esgoto nos FBPs, as emissões de óxido nitroso $\left(\mathrm{N}_{2} \mathrm{O}\right)$ se destacaram pelo elevado impacto na categoria de depleção de ozônio estratosférico (SOD). O emprego do lodo na agricultura obteve um maior potencial de impacto ambiental, em relação ao aterro sanitário, em 5 das 8 categorias avaliadas. Os principais impactos do uso agrícola foram na categoria de toxicidade humana (HT), devido à elevada concentração de zinco presente no lodo, e na categoria de acidificação terrestre (TA), em virtude da emissão de amônia $\left(\mathrm{NH}_{3}\right)$ durante a higienização do lodo. Por sua vez, os principais aspectos positivos foram os produtos evitados como ureia, fertilizante fosfatado e calcário. Os resultados reportados contribuem para uma maior discussão dos processos de tratamento de esgoto, bem como de alternativas de gerenciamento de lodo, empregados em países em desenvolvimento.

Palavras-chave: aterro sanitário, avaliação ambiental, biogás, dióxido de nitrogênio, estabilização alcalina, lodo biológico.

\section{INTRODUCTION}

Population growth in Latin America and the Caribbean (LAC) has surpassed the capacity of national and local governments to meet the demand for basic sanitation services, especially those inherent in the collection and treatment of sewage (Noyola et al., 2012). In Brazil, recent data from Agência Nacional de Águas (ANA; National Water Agency) confirm this problem by disclosing that the sanitary sewage collection rate in the country is $61.4 \%$, and that only $42.6 \%$ of all sewage generated is treated (ANA, 2017). These data indicate that approximately 65 million Brazilians still do not have access to a collective system to remove sewage, and about 97 million do not have the sewage from their homes treated. Therefore, new sewage treatment plants (STPs) and the expansion of the capacity and treatment level of existing STPs should be planned in the coming years, since the intention is to universalize sewage servicers in the country.

One of the sewage technologies that should continue to be widely used in Brazil is that of upflow anaerobic sludge blanket (UASB) rectors. Present in 1,047 STPs, UASB reactors represent the most used treatment technology in the country (ANA, 2017). This is mainly due to low costs of implementation and operation compared to aerobic treatment systems (Chernicharo et al., 2018). In addition, UASB reactors are responsible for the production of biogas, which is endowed with energy potential because it contains methane $\left(\mathrm{CH}_{4}\right)$ in its composition and can therefore be used for energy purposes within the treatment plant itself (Moran et al., 2010). However, it should be noted that most Brazilian STPs collect biogas and conducted it to flares, in order to reduce rates of greenhouse gas emissions (Amaral et al., 2018; Possetti et al., 2019), since $\mathrm{CH}_{4}$ has a global warming potential 34 times greater than that of carbon dioxide $\left(\mathrm{CO}_{2}\right)$ (IPCC, 2014). An additional aim of burning biogas is to reduce problems related to bad odors and equipment corrosion due to hydrogen sulfide $\left(\mathrm{H}_{2} \mathrm{~S}\right)$ present in the medium (Possetti et al., 2018). However, if $\mathrm{H}_{2} \mathrm{~S}$ destruction occurs in low-efficiency burners, sulfur dioxide $\left(\mathrm{SO}_{2}\right)$ may form in the atmosphere (Possetti et al., 2018).

Despite the recognized advantages, it should be emphasized that exclusive use of UASB reactors may be insufficient to meet legal requirements for discharging effluents into bodies of water (Almeida et al., 2018). Thus, aerobic treatment processes, such as activated sludge and, mainly, trickling filters (TFs), are being used in Brazil as a stage for post-treatment of effluents 
from UASB reactors. The efficiency of removing organic matter in TFs systems can vary according to the hydraulic rate applied to its surface, or even the organic load applied to the volume of the percolating filter media, thus resulting in three possible types of TFs: low rate (1 to $4 \mathrm{~m}^{3} \cdot \mathrm{m}^{-2} \cdot \mathrm{d}^{-1}$ or 0.08 to $\left.0.4 \mathrm{kgBOD} \cdot \mathrm{m}^{-3} \cdot \mathrm{d}^{-1}\right)$, intermediate rate $\left(4\right.$ to $10 \mathrm{~m}^{3} \cdot \mathrm{m}^{-2} \cdot \mathrm{d}^{-1}$ or 0.4 to 0.48 kgBOD. $\left.\mathrm{m}^{-3} \cdot \mathrm{d}^{-1}\right)$ and high rate $\left(10\right.$ to $40 \mathrm{~m}^{3} \cdot \mathrm{m}^{-2} \cdot \mathrm{d}^{-1}$ or 0.48 to $1.0 \mathrm{kgBOD} \cdot \mathrm{m}^{-3} \cdot \mathrm{d}^{-1}$ ) (Metcalf \& Eddy, 2016).

Low-rate TFs have an organic removal efficiency of more than $80 \%$, with high effluent nitrification capacity (Corrêa, 2019). Although nitrification reduces the environmental problems intrinsic to the discharge of effluents into water bodies, it should be emphasized that it is responsible for the production of nitrous oxide $\left(\mathrm{N}_{2} \mathrm{O}\right)$ (Vasilaki et al., 2019), which has a global warming potential 265 times greater than $\mathrm{CO}_{2}$ (IPCC, 2014). Still, TFs can also be a source of $\mathrm{CH}_{4}$ emissions, since up to $40 \%$ of this biogas remains dissolved in the effluent of the UASB reactors and can be released in the post-treatment stage (Souza et al., 2011). Within this context, STPs that employ UASB reactors followed by low-rate TFs can become a significant source of $\mathrm{CH}_{4}$ and $\mathrm{N}_{2} \mathrm{O}$ (El-Fadel e Massoud, 2001). Studies referring to the assessment of environmental impacts of systems composed of UASB reactors followed by low-rate TFs are incipient (Bressani-Ribeiro et al., 2017), and there is still no integrated discussion of the environmental problems inherent to these two treatment technologies.

In addition to the issues of gaseous emissions arising from sewage treatment, another byproduct generated by STPs that can bring a series of significant environmental impacts is sludge (Amaral et al., 2019). Characterized by high concentrations of nutrients and organic matter, sludge can be used as a fertilizer in agriculture (Bittencourt, 2014; Cieslik et al., 2015). However, sludge also has high levels of water and pathogenic microorganisms and, thus, processes of dewatering and hygienization must be performed for its use as a biofertilizer (Lobato et al., 2018). A practice adopted by some sanitation companies in Brazil is to dewater sludge, in drying beds or in centrifuges, followed by prolonged alkaline stabilization (PAS).

The process of PAS consists of raising the $\mathrm{pH}$ of the sludge to 12 for a minimum period of 2 hours by the application of chemical products, such as lime, for example. The mixture must be sufficient to ensure that the entire mass of the sludge in contact with the lime suffers an increase in $\mathrm{pH}$ (USEPA, 1992). It should be noted that during this process there is a release of ammonia $\left(\mathrm{NH}_{3}\right)$, which is another significant point of emission in an STP that employs such a procedure (Amaral et al., 2019). After the mixing step, the sludge must be sent to a curing and storage yard, where it will remain for a period of 35 to 45 days (Andreoli et al., 2014). Despite being considered a recognized practice worldwide, the agricultural destination of sewage sludge is performed by few sanitation companies in Brazil. This is mainly due to the difficulty that these companies have in meeting the criteria and procedures established by Brazilian legislation for agricultural use (Bittencourt et al., 2014). Thus, the main destination of the sludge produced in Brazilian STPs remains the sanitary landfill. Studies of environmental impacts resulting from sludge disposal alternatives in developing countries (Hernandez-Padilla et al., 2017; Amaral et $a l ., 2018$ ), whether in agricultural areas or landfills, are also incipient.

Based on the understanding of the need for new studies based on the survey of environmental impacts in STPs, it should be emphasized that the development of inventories, as well as the application of decision-making tools such as the Life Cycle Assessment (LCA), are fundamental for the identification of strategies to mitigate environmental impacts and in the choice of environmentally correct alternatives for sewage treatments and final disposal of sludge. In this context, the objective of this article was to carry out an environmental LCA of an STP that employs UASB reactors followed by low-rate TFs, with the a primary focus on $\mathrm{CH}_{4}, \mathrm{H}_{2} \mathrm{~S}, \mathrm{~N}_{2} \mathrm{O}$ and $\mathrm{NH}_{3}$ emissions to the atmosphere, as well as on comparing environmental impacts between the sludge disposal alternatives of landfills and agricultural areas. 


\section{MATERIALS AND METHODS}

\subsection{Study area}

To meet the objective of the present study, a small STP located in the South Region of Brazil, was used as a study area. With a capacity to treat sewage of a population of up to 52 thousand inhabitants, the plant has a design flow equal to $90 \mathrm{~L} . \mathrm{s}^{-1}$. The treatment system adopted at the STP, consists: preliminary treatment (course and fine screens, grit chamber and a Parshall flow meter); 03 (three) UASB reactors; 02 (two) low-rate TFs and 02 (two) circular secondary decanters. To maintain the active biota in the biofilm during periods of low flow (dawn, for example), the effluent from the TFs is recirculated. More detailed information about the UASB reactors and the TFs implanted in the studied STP are shown in Table 1.

Table 1. Characteristics of the UASB reactors and the TFs implanted in the STPs under study.

\begin{tabular}{lcc}
\hline Parameters & UASB reactors & TFs \\
\hline Population (inhab) & $34,000(52,000)^{*}$ \\
\hline Flow rate $\left(\mathrm{L} \cdot \mathrm{s}^{-1}\right)$ & $33(90)^{*}$ \\
\hline Hydraulic retention time $(\mathrm{h})$ & $11.3(8.0)^{*}$ & - \\
\hline Volumetric organic load $\left(\mathrm{kgBOD} \cdot \mathrm{m}^{-3} \cdot \mathrm{d}^{-1}\right)$ & 0.8 & $0.1-0.4$ \\
\hline Volumetric hydraulic load $\left(\mathrm{m}^{3} \cdot \mathrm{m}^{-2} \cdot \mathrm{d}^{-1}\right)$ & - & $1-4$ \\
\hline Number of reactors & 3 & 2 \\
\hline Type & Trunk-conical & Circular \\
\hline Diameter of each reactor $(\mathrm{m})$ & 18 & 22 \\
\hline Useful depth of each reactor $(\mathrm{m})$ & 5.75 & 3.0 \\
\hline Useful volume of each reactor $\left(\mathrm{m}^{3}\right)$ & 800 & 1,140 \\
\hline
\end{tabular}

* Values in parentheses refer to design parameters.

The waste produced in the preliminary treatment (waste from the screens and grit chamber) is sent to a landfill. The sludge from the UASB reactors and secondary decanters is directed to cover conventional drying beds. After the dewatering process, the sludge is sent for hygienization in a Sludge Management Unit (SMU) for the PAS process to be carried out. After the curing period, the sludge can be made available for agricultural areas. In sporadic situations, after the dewatering process in the drying beds, the sludge can be sent to a sanitary landfill without the need, therefore, for the hygienization step. Finally, the biogas produced in the UASB reactors is collected and conducted to flares with low $\mathrm{CH}_{4}$ destruction efficiency.

\subsection{Elaboration of environmental inventories for LCA}

The elaboration of environmental inventories of the domestic sewage treatment processes, as well as the sludge management alternatives used in the STP, took place through the use of primary (measured) and secondary (bibliographical references/data of Ecoinvent ${ }^{\circledR}$ database) data of parameters correlated with the gaseous, liquid and solid phases of the STP (Figure 1). The chosen functional unit for the study was the treatment of $1 \mathrm{~m}^{3}$ of sewage. Another parameter considered in the study was the consumption of electricity in the treatment plant. These data were obtained directly from the sanitation company responsible for the STP. 


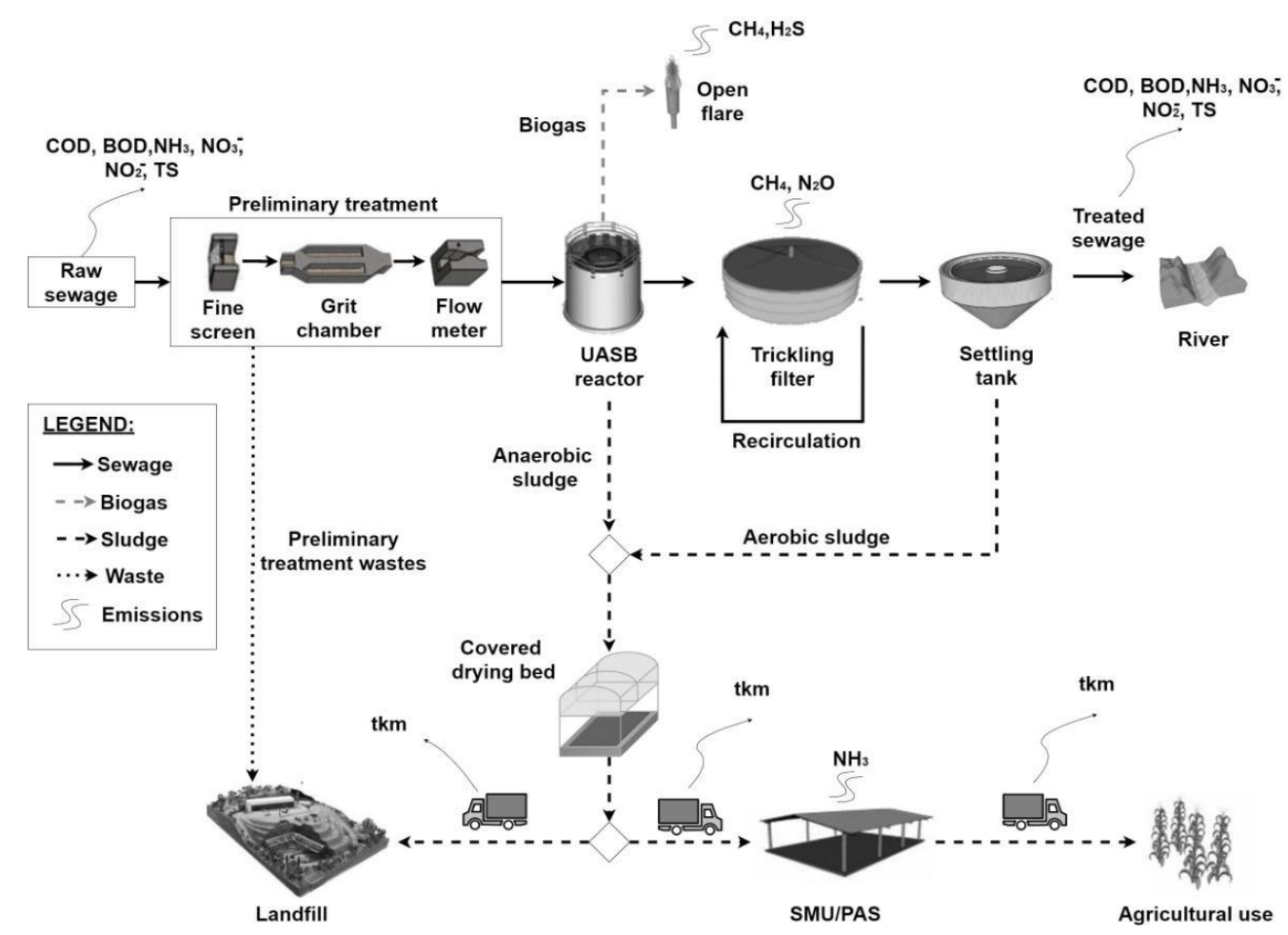

Figure 1. Schematic diagram of the gaseous, liquid and solid phases in the STP under study.

\subsubsection{Gaseous phase}

Environmental inventory of the gaseous phase included the following: flow and characterization of the biogas produced in the UASB reactors; efficiency of flares with respect to the destruction of $\mathrm{CH}_{4}$ and $\mathrm{H}_{2} \mathrm{~S}$; emission rates of $\mathrm{N}_{2} \mathrm{O}$ and $\mathrm{CH}_{4}$ in TFs; and emissions of $\mathrm{NH}_{3}$ during PAS of the sewage. The study also took into account emissions related to the transportation of lime to the STP (for the PAS process), the transportation of sludge to the agricultural area or sanitary landfill, and the process of applying the sanitized sludge to the agricultural area.

The flow of biogas produced in the UASB reactors was calculated using ProBio 1.0 software (2021). The input data required by the software were sewage flow and chemical oxygen demand (COD) affluent to the UASB reactors. These data were obtained from the STP and refer to average values found during 2018. The values reported by Lobato et al. (2012) were used for biogas composition, being, in volumetric relations $\left(\mathrm{v} \cdot \mathrm{v}^{-1}\right)$, equal to: $70 \%$ for $\mathrm{CH}_{4}$ and 1,500 ppm for $\mathrm{H}_{2} \mathrm{~S}$. The destruction efficiency for $\mathrm{CH}_{4}$ and $\mathrm{H}_{2} \mathrm{~S}$ in flares was obtained through studies carried out by Kaminski et al. (2018). According to these authors, this type of burner has a destruction efficiency, on average, for these gases of $50 \%$.

Regarding emissions of $\mathrm{N}_{2} \mathrm{O}$ and $\mathrm{CH}_{4}$ in the TFs of the STP, the reference values of a domestic sewage treatment system of the constructed vertical wetland type were used (Fuchs $e t$ al., 2011; Gutierrez, 2014). It should be noted that the adoption of these values was due to the hydraulic similarity between the systems and also due to the fact there are no emission data in literature for $\mathrm{N}_{2} \mathrm{O}$ and $\mathrm{CH}_{4}$ in TFs at full scale. Thus, emissions of $2.68 \mathrm{gCH} 4 . \mathrm{m}^{-3}$ sewage and 0.23 $\mathrm{gN} 2 \mathrm{O} . \mathrm{m}^{-3}$ sewage in TFs were considered. The $\mathrm{NH}_{3}$ emission value, in the PAS of sludge, was obtained from studies carried out by Amaral et al. (2018), who found an average emission value of $1.2 \mathrm{gNH}_{3} . \mathrm{m}^{-3}$ sewage. Emissions related to the transportation of lime to the STP, as well as the destinations of the waste from the preliminary treatment and the dewatered sludge, whether an agricultural area or landfill, were reported according to the parameter tkm, which considers the mass transported (in tons) and the distance covered (round trip in kilometers). Finally, 
emissions related to the application of sludge in agriculture areas followed the models presented by Nemecek and Schnetzer (2011), according to the study of Amaral et al. (2018).

\subsubsection{Liquid phase}

Environmental inventory of the liquid phase considered the following parameters for the influent and effluent of the STP: COD, biochemical oxygen demand (BOD5), $\mathrm{NH}_{3}$, nitrate $\left(\mathrm{NO}_{3}{ }^{-}\right)$, nitrite $\left(\mathrm{NO}_{2}{ }^{-}\right)$and total solids (TS). Collections were performed at these points during two 24-hour sampling campaigns in the years of 2017 and 2018. The analyses followed the procedures established in Standard Methods for the Examination of Water and Wastewater (Apha et al., 2012).

\subsubsection{Solid phase}

The amount of waste from the preliminary treatment was obtained from the monthly average of 2018 in the STP. The amount of total solids (TS) in the biological sludge from the UASB reactors and the TFs was estimated from the COD applied at the STP. For this, the production of TS in UASB reactors followed by aerobic-post-treatment was used, which is 0.25 kgST.kgCOD applied (Andreoli et al., 2014).

The environmental inventory of the hygienized sludge application process in agricultural areas took into account the models reported by Nemecek and Schnetzer (2011). The input data required for the modeling were: nitrogen $(\mathrm{N})$ and phosphorus $(\mathrm{P})$ content in the hygienized sludge, characteristics of the soil where the sludge is to be disposed and the products avoided by the agricultural use of the sludge. Thus, the levels of $\mathrm{N}$ and $\mathrm{P}$ used were $10.2 \mathrm{~g} \cdot \mathrm{kg}^{-1}$ and 3.6 g. $\mathrm{kg}^{-1}$, respectively. The soil type considered was Haplic Cambisol with its specific characteristics of clay content, organic carbon content and the amount of eroded soil. For the application of hygienized sludge in the agricultural area, urea (with $45 \%$ nitrogen content), phosphate fertilizer $\left(\mathrm{P}_{2} \mathrm{O}_{5}\right)$ and limestone were considered as avoided products. This step used the characterization data for hygienized sludge reported by Amaral et al. (2018).

Data relating to the manufacture of products avoided in agricultural use, the manufacture of polymer (used for dewatering), the manufacture of lime, the type of transport by motor vehicles and the production of diesel for fuel and electricity generation were obtained through the Ecoinvent ${ }^{\circledR}$ database. For lime, Relative Power of Total Neutralization (RPNT) of $75 \%$ was considered, while a RPNT of $110 \%$ was considered for lime (contained in biological sludge) (Bittencourt, 2014). Finally, since there are no specific environmental inventories of impacts related to sludge deposited in landfills, the present study used data of environmental inventories of a landfill that receives sludge from the paper industry. This consideration was made due to the composition and biodegradability of this material being closer to those of STP sludge used in Brazilian landfills.

\subsection{Assessment of environmental impacts}

The environmental impact was calculated using the LCA methodology and SimaPro® 9 software. The method used was ReCiPe 2016 Midpoint (H). The assessed impact categories were: global warming $(\mathrm{GW})$, stratospheric ozone depletion (SOD), ozone formation - terrestrial ecosystems (OTE), terrestrial acidification (TA), aquatic eutrophication (fresh water) (EUTAW), terrestrial ecotoxicity (TE), freshwater ecotoxicity (FWE) and human toxicity - non cancer (HT).

\section{RESULTS AND DISCUSSION}

\subsection{Environmental inventory of the processes used in the STP}

Table 2 shows the environmental inventory of the flows, into and out, of the phases 
(gaseous, liquid and solid) referring to the sewage treatment processes (preliminary treatment, UASB reactors, TFs, secondary decanters) and the different sludge management alternatives (destination for landfill or agricultural area) employed at the studied STP.

Samples of sewage affluent to the STP had values within the ranges for typical concentrations of domestic sewage found in the literature (Aisse, 2002; Von Sperling, 2014). The average efficiency of the STP for removing COD and $\mathrm{BOD}_{5}$ was over $87 \%$. For the nitrification process, the average reduction of $\mathrm{NH}_{3}$ in the TFs was $43 \%$. Similar results were obtained by Lopes et al. (2018) in vertical wetlands as a post-treatment step for UASB reactors. The estimate of biogas production in the UASB reactors was $341 \mathrm{~m}^{3} \cdot \mathrm{d}^{-1}$. Considering the lower calorific power (LCP) of $\mathrm{CH}_{4}$ equal to $9.9 \mathrm{kWh} \cdot \mathrm{m}^{-3}$, the chemical potential that could be used in the STP would be approximately $3,376 \mathrm{kWh} . \mathrm{d}^{-1}$. This potential is not greater, due to fugitive emissions in the reactor and the $\mathrm{CH}_{4}$ not recovered in the biogas, that remains dissolved in the treated effluent. According to Souza et al. (2011), concentrations of 17 to $22 \mathrm{mg} . \mathrm{L}^{-1}$ of $^{-\mathrm{CH}_{4}}$ can be found in liquid medium. Regarding the destination of the sludge, it should be noted that the distance from the STP to the SMU, and from this to the agricultural area, increased the parameter of tkm by approximately two times in relation to disposal in landfill.

Table 2. Inventory of the Life Cycle of processes used in the STP.

\begin{tabular}{|c|c|c|}
\hline Inputs (Pollutants in domestic wastewater) & Concentration (mg. $\left.\mathrm{L}^{-1}\right)$ & Correlated to functional unit \\
\hline Chemical oxygen demand (COD) & 565.0 & $0.565 \mathrm{~kg} \cdot \mathrm{m}^{-3}$ \\
\hline Biochemical oxygen demand (BOD) & 293.0 & $0.293 \mathrm{~kg} \cdot \mathrm{m}^{-3}$ \\
\hline Unionized ammonia $\left(\mathrm{NH}_{3}-\mathrm{N}\right)$ & 65.7 & $0.066 \mathrm{~kg} \cdot \mathrm{m}^{-3}$ \\
\hline Nitrate $\left(\mathrm{NO}_{3}{ }^{-}-\mathrm{N}\right)$ & 1.2 & $0.0012 \mathrm{~kg} \cdot \mathrm{m}^{-3}$ \\
\hline Nitrite $\left(\mathrm{NO}_{2}^{-}-\mathrm{N}\right)$ & 0.2 & $0.0002 \mathrm{~kg} \cdot \mathrm{m}^{-3}$ \\
\hline Input (energy) & Demand (kWh.d-1) & Correlated to functional unit \\
\hline Electricity consumed & $1,086.5$ & $0.38 \mathrm{kWh} . \mathrm{m}^{-3}$ \\
\hline Emissions to water (final treated effluent) & Concentration (mg.L $\left.\mathrm{L}^{-1}\right)$ & Correlated to functional unit \\
\hline Chemical oxygen demand (COD) & 68.0 & $0.068 \mathrm{~kg} . \mathrm{m}^{-3}$ \\
\hline Biochemical oxygen demand (BOD) & 17.0 & $0.017 \mathrm{~kg} \cdot \mathrm{m}^{-3}$ \\
\hline Unionized ammonia $\left(\mathrm{NH}_{3}-\mathrm{N}\right)$ & 37.5 & $0.0375 \mathrm{~kg} \cdot \mathrm{m}^{-3}$ \\
\hline Nitrate $\left(\mathrm{NO}_{3}^{-}-\mathrm{N}\right)$ & 9.0 & $0.009 \mathrm{~kg} \cdot \mathrm{m}^{-3}$ \\
\hline Nitrite $\left(\mathrm{NO}_{2}^{-}-\mathrm{N}\right)$ & 5.0 & $0.005 \mathrm{~kg} \cdot \mathrm{m}^{-3}$ \\
\hline Total solids (TS) & 19.0 & $0.019 \mathrm{~kg} \cdot \mathrm{m}^{-3}$ \\
\hline Biogas production in UASB reactors & Flow rate $\left(\mathbf{m}^{3} \cdot \mathbf{d}^{-1}\right)$ & Correlated to functional unit \\
\hline Biogas $\left(70 \%-\mathrm{CH}_{4}\right.$ and $\left.1,500 \mathrm{ppm}-\mathrm{H}_{2} \mathrm{~S}\right)$ & 341.1 & \\
\hline Emissions to air & Flow rate $\left(\mathbf{m}^{3} \cdot d^{-1}\right)$ & Correlated to functional unit \\
\hline Methane $\left(\mathrm{CH}_{4}\right)^{\mathrm{a}}$ & 119.4 & $0.042 \mathrm{~m}^{3} \cdot \mathrm{m}^{-3}$ \\
\hline Hydrogen sulfide $\left(\mathrm{H}_{2} \mathrm{~S}\right)^{\mathrm{a}}$ & 0.26 & $0.00009 \mathrm{~m}^{3} \cdot \mathrm{m}^{-3}$ \\
\hline Nitrous oxide $\left(\mathrm{N}_{2} \mathrm{O}\right)$ - Trickling filter & & $0.23 \mathrm{~g} \cdot \mathrm{m}^{-3}$ \\
\hline Methane $\left(\mathrm{CH}_{4}\right)-$ Trickling filter $^{\mathrm{b}}$ & & $2.68 \mathrm{~g} \cdot \mathrm{m}^{-3}$ \\
\hline Solid waste & Production (kg.d $\left.{ }^{-1}\right)$ & Correlated to functional unit \\
\hline Preliminary treatment waste & 82.6 & $0.029 \mathrm{~kg} \cdot \mathrm{m}^{-3}$ \\
\hline Dewatered sludge & 500.0 & $0.17 \mathrm{~kg} \cdot \mathrm{m}^{-3}$ \\
\hline Solid waste transportation & Mass x distance (tkm) & Correlated to functional unit \\
\hline Preliminary treatment waste - Landfill & & $0.0033 \mathrm{tkm} \cdot \mathrm{m}^{-3}$ \\
\hline Dewatered sludge - Landfill & & $0.066 \mathrm{tkm} \cdot \mathrm{m}^{-3}$ \\
\hline Dewatered sludge - Agricultural area & & $0.01412 \mathrm{tkm} \cdot \mathrm{m}^{-3}$ \\
\hline
\end{tabular}

${ }^{a}$ Considering an efficiency of $50 \%$ destruction in the flare; ${ }^{b}$ Methane dissolved $\left(\mathrm{CH}_{4}\right.$ dissolved $)$ in the UASB reactor effluent emitted in the Trickling filter. 


\subsection{Environmental assessment of the STP with sludge being destined to landfill}

Figure 2 shows the contribution of each process used in the STP to the impact categories evaluated for the landfill sludge disposal scenario. The biggest contribution to the GW category, with a 53\% influence, was the stage of burning the $\mathrm{CH}_{4}$ produced in the UASB reactors. Due to the low efficiency of flares $(\sim 50 \%)$, a significant portion of $\mathrm{CH}_{4}$ is still emitted into the atmosphere. With a $\mathrm{CH}_{4}$ flow rate equal to $238 \mathrm{~m}^{3} . \mathrm{d}^{-1}$ in the UASB reactors $(70 \%$ in relation to biogas), it is calculated that $119 \mathrm{~m}^{3} \cdot \mathrm{d}^{-1}$ of this gas is emitted into the atmosphere by the burners. Considering a density of $0.657 \mathrm{~kg} \cdot \mathrm{m}^{-3}$ and a global warming potential 34 times higher than $\mathrm{CO}_{2}$, the flow of $\mathrm{CH}_{4}$ emitted corresponds to an average rate of greenhouse gas emissions of approximately 1,000 $\mathrm{tCO}_{2}$ eq.year ${ }^{-1}$. The TFs and the final effluent of the STP are also considered to be $\mathrm{CH}_{4}$ emission sources, contributing about $25 \%$ of the impacts to the GW category. Finally, the sending of sludge to landfill contributed about $14 \%$ to the environmental impacts that occurred in the GW category. This percentage is associated with $\mathrm{CH}_{4}$ and $\mathrm{CO}_{2}$ produced during the degradation of this material in landfill cells.

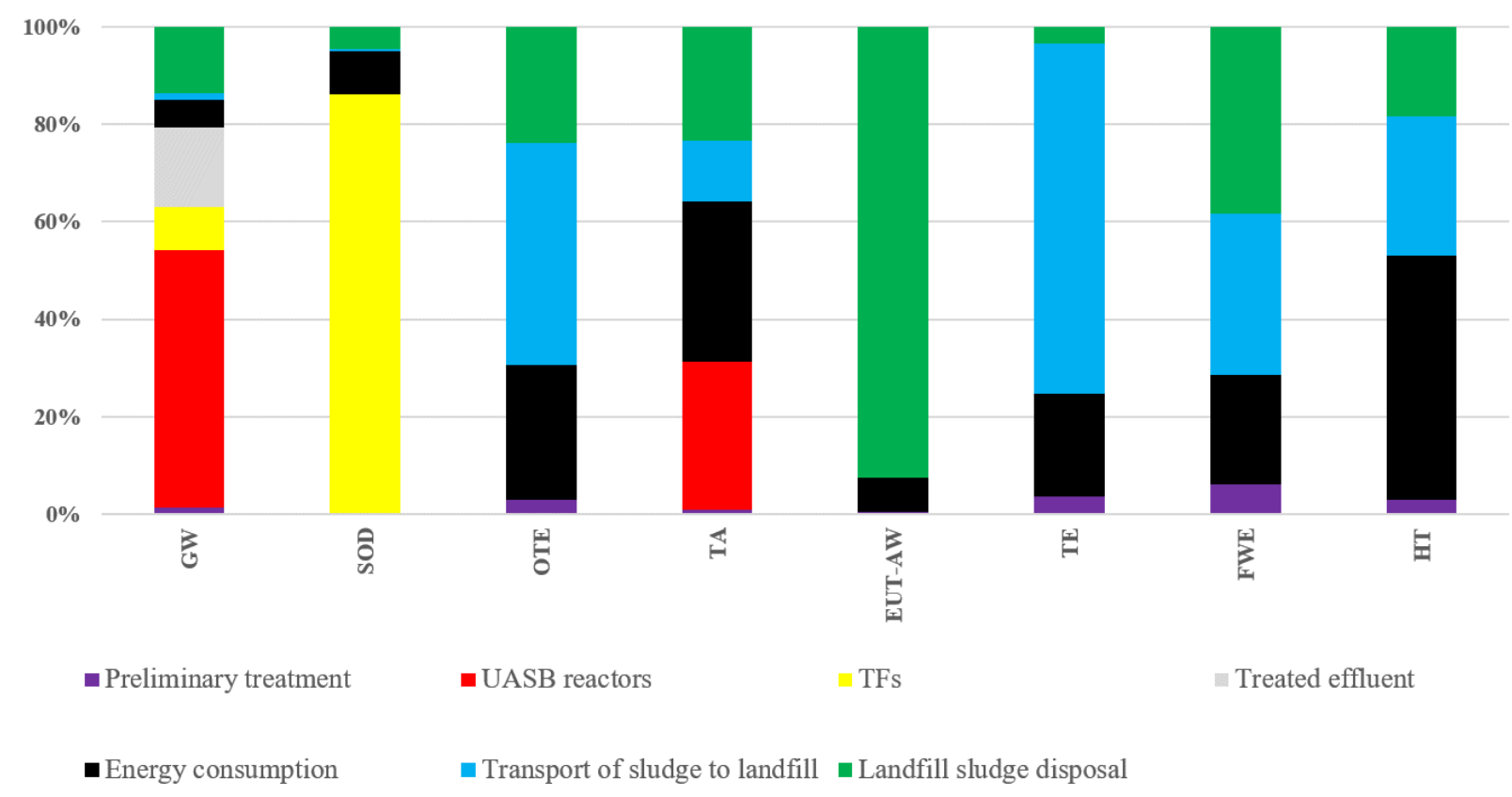

Figure 2. Contribution of each treatment step in the categories of environmental impacts evaluated considering the destination of sludge in landfill.

The process with the greatest influence on the SOD category was the TFs (86\%) due to $\mathrm{N}_{2} \mathrm{O}$ emissions. In the stratosphere, $\mathrm{N}_{2} \mathrm{O}$ plays an important catalytic role in the consumption of stratospheric ozone $\left(\mathrm{O}_{3}\right)$, having a residence time in the media of up to 120 years (Ravishankara et al., 2009). One way to reduce the impacts caused by the emission of this gas in TFs is to carry out more adequate control of the aeration process. It should be noted that the alternative of sending the sludge to landfill contributes only about $5 \%$ to the environmental impacts of the SOD category.

The process of transporting sludge to landfills had an approximately $45 \%$ influence on the impacts caused in the OTE category. This is mainly due to emissions of nitrogen oxides $\left(\mathrm{NO}_{\mathrm{x}}\right)$ from the use of diesel as a fuel in motor vehicles. $\mathrm{NO}_{\mathrm{x}}$ is a major contributor to increased ozone concentration on the Earth's surface, which in turn contributes to the worsening of air pollution in cities and acid rain (Quiros et al., 2017). As for OTE, the TE category also had the transport of sludge to the landfill as the main environmental impact process, with an influence of approximately $72 \%$. This influence is due to copper (heavy metal) emissions resulting from wear and tear on brakes in motor vehicles. Vehicle brake systems are made up of brake pads 
composed mainly of copper fibers. The pad, when forced by the rotating brake disc, generates wear on the fibers causing the emission of copper (Simons, 2013). Tire wear during the sludge transport process was one of the main factors responsible for the impacts measured in the FWE category. Still, for this category, zinc present in landfill leachate contributed approximately $40 \%$ of the impacts.

The most impactful process in the TA category, with a $30 \%$ influence, was the emission of sulfur dioxide $\left(\mathrm{SO}_{2}\right)$ and $\mathrm{H}_{2} \mathrm{~S}$ in the burners of the UASB reactors. As the burners are unable to fully combust the biogas, $\mathrm{SO}_{2}$ is formed and emitted into the atmosphere. The transportation and disposal of sludge in landfills had an influence of about $36 \%$ on the TA category. This is also due to $\mathrm{SO}_{2}$ (produced during sludge transport due to the possibility of incomplete burning of diesel).

The process that contributed most to the EUT-AW category was the destination of sludge in landfills, with $92 \%$. This is due to the high presence of phosphate $\left(\mathrm{PO}_{4}{ }^{{ }^{3}}\right)$ in the leachate in the landfill. The inventory used considered the emission of $0.437 \mathrm{gPO}_{4}{ }^{3-} \cdot \mathrm{kg}^{-1}$ of waste to the river and $0.272 \mathrm{gPO}_{4}{ }^{3-} \cdot \mathrm{kg}^{-1}$ to groundwater. In the HT category, the processes of transportation and disposal of sludge in landfills had an influence of approximately $50 \%$.

\subsection{Environmental assessment of the STP with sludge destined for agriculture use}

Figure 3 shows the contribution of each process used in the STP considering sludge disposal in agriculture. For the GW category, $\mathrm{CH}_{4}$ emissions to the atmosphere in the UASB reactors, TFs and final effluent remain the main sources of environmental impact. Sludge transport and final destination for agriculture only had a 5\% influence on this category. In turn, the agricultural use of sludge was responsible for approximately $80 \%$ of the impacts in the TA category, which is mainly due to the emission of $\mathrm{NH}_{3}$ in the PAS process. Although the application of lime raises the $\mathrm{pH}$ in the sludge, ensuring the reduction of pathogenic microorganisms (Bittencourt, 2014), this process also causes a significant amount of $\mathrm{NH}_{3}$ to be volatized.

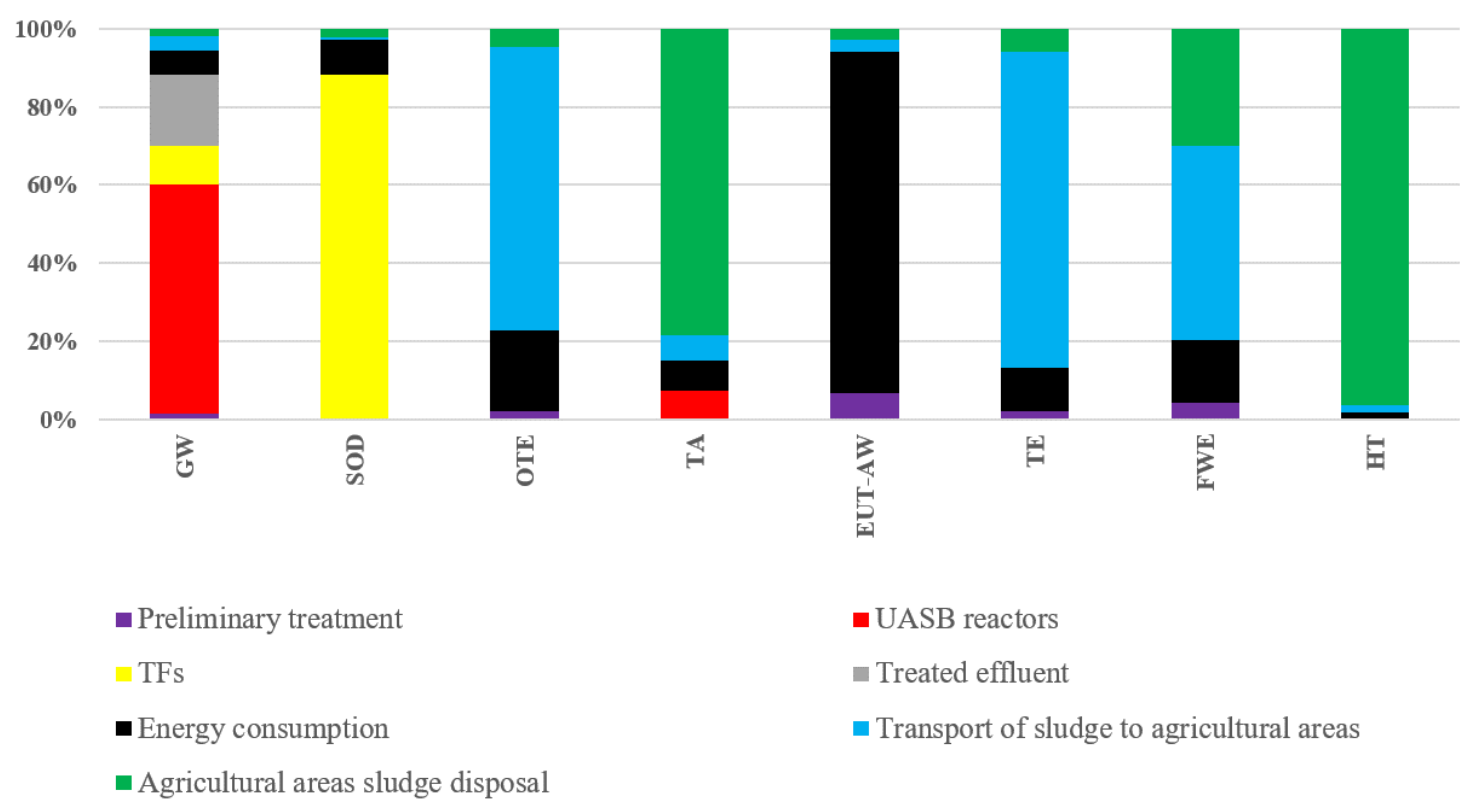

Figure 3. Contribution of each treatment step in the categories of environmental impacts evaluated considering the destination of sludge in agricultural areas.

In the SOD category, $\mathrm{N}_{2} \mathrm{O}$ emissions in TFs continued to be the main contributor responsible for the measured environmental impacts. The destination of sludge in agriculture 
was responsible for only $3 \%$ of the impacts caused in this category. Sludge transport was responsible for contributing approximately $70 \%$ of the impacts caused in the OTE category (due to $\mathrm{NO}_{\mathrm{x}}$ emissions form the use of diesel) and $80 \%$ of the impacts in the TE category (due to copper emissions).

The transport and use of sludge in the agricultural area were responsible for about $80 \%$ of the impacts measured in the FWE category. With regard to transport, tire wear was the main source of impact. In sludge application, the high concentration of zinc (heavy metal) in the sludge ( $514 \mathrm{mg} \cdot \mathrm{kg}^{-1}$ ) used in the present study, and reported by Amaral et al. (2018), was responsible for the impacts in this category. According to Kummer et al. (2018), zinc has a low potential for adsorption in soils and, thus, is easily leached into rivers and groundwater.

The avoided products (urea, phosphate fertilizer and limestone), due to the use of sludge in agricultural areas, contributed to this alternative, having an impact on the EUT-FW category of only $4 \%$. Finally, in the HT category, the agricultural disposal of sludge was responsible for $95 \%$ of the environmental impacts, which was due to the high concentration of zinc (heavy metal) in the sludge. Results obtained by Yoshida et al. (2018) also highlighted the impact of the application of sludge containing a high concentration of zinc on the soil. According to these authors, zinc was responsible for 85 to $92 \%$ of the impacts caused in the HT category.

\subsection{Comparative LCA}

The absolute values of the contribution of each process used in the STP, with the different alternatives for final disposal of the sludge, are shown in Table 3. In general, the agricultural use of sludge obtained a greater potential for environmental impact in the following categories: OTE, TA, TE, FWE and HT.

The agricultural use of the sludge had a greater impact on the categories OTE, TE and FWE compared to destination in landfill due to the greater distances traveled to carry out the hygienization and disposal of the sludge, thus resulting in greater wear and tear on vehicle and also higher rates of $\mathrm{NO}_{\mathrm{x}}$ and copper emissions into the atmosphere. In the TA category, $\mathrm{NH}_{3}$ emissions during the PAS process were responsible for the greater impact of the agricultural use of sludge. As shown in Figure 3, of all the categories investigated, the one with the greatest impact from the agricultural disposition of sludge was HT, due to the high concentration of zinc in the sludge. This parameter has a characterization factor of $1.29 \times 10^{6}$ by the method used for emission in agricultural soil, which causes a great impact for this destination.

Table 3. Life Cycle Assessment of processes used in the STP.

\begin{tabular}{|c|c|c|c|c|c|}
\hline \multirow{2}{*}{ Impact categories } & \multirow{2}{*}{ Units } & \multicolumn{2}{|c|}{ Transport } & \multicolumn{2}{|r|}{ Disposal } \\
\hline & & Landfill & Agricultural areas & Landfill & Agricultural areas \\
\hline GW & $\mathrm{kgCO}_{2} \mathrm{eq}$ & 0.027 & 0.059 & 0.241 & 0.029 \\
\hline SOD & $\mathrm{kg}$ CFC $11 \mathrm{eq}$ & $8.18 \times 10^{-9}$ & $1.75 \times 10^{-8}$ & $1.37 \times 10^{-7}$ & $5.99 \times 10^{-8}$ \\
\hline OTE & $\mathrm{kg} \mathrm{NO}_{\mathrm{x}} \mathrm{eq}$ & $1.83 \times 10^{-4}$ & $3.92 \times 10^{-8}$ & $9.64 \times 10^{-5}$ & $2.74 \times 10^{-5}$ \\
\hline TA & $\mathrm{kg} \mathrm{SO}_{2} \mathrm{eq}$ & $9.50 \times 10^{-5}$ & $2.03 \times 10^{-4}$ & $1.79 \times 10^{-4}$ & $2.54 \times 10^{-3}$ \\
\hline EUT-AW & $\mathrm{kg} P$ eq & $3.24 \times 10^{-8}$ & $6.93 \times 10^{-8}$ & $2.63 \times 10^{-5}$ & $6.54 \times 10^{-8}$ \\
\hline TE & $\mathrm{kg} 1,4-\mathrm{DCB}$ eq & $6.84 \times 10^{-5}$ & $1.46 \times 10^{-4}$ & $3.27 \times 10^{-6}$ & $1.06 \times 10^{-5}$ \\
\hline FWE & $\mathrm{kg} 1,4-\mathrm{DCB}$ eq & $4.56 \times 10^{-5}$ & $9.75 \times 10^{-5}$ & $5.29 \times 10^{-5}$ & $5.90 \times 10^{-5}$ \\
\hline HT & $\mathrm{kg} 1,4-\mathrm{DCB}$ eq & 0.113 & 0.243 & $7.38 \times 10^{-2}$ & 12.69 \\
\hline
\end{tabular}

\section{CONCLUSIONS}

The destination of sewage sludge for agriculture, under the conditions addressed here, had a greater potential for impact in five of the eight categories evaluated. It should be noted that in this article, for comparison purposes, a landfill from the Ecoinvent ${ }^{\circledR}$ database was used, which receives sludge form the paper and cellulose industry. The main impacts observed in the process 
of agricultural use of sludge are related to the concentration of zinc present, which significantly affects the FWE and HT categories. On the other hand, the main benefits of the agricultural use of sludge were avoided products, such as urea, phosphate fertilizer and limestone. The main impacts related to the disposal of sludge in landfills were limited to $\mathrm{CH}_{4}$ emissions to the atmosphere and the $\mathrm{PO}_{4}{ }^{3-}$ load present in the leachate. The results of the sewage treatment processes used in the studied STP showed the problem of $\mathrm{CH}_{4}$ and $\mathrm{N}_{2} \mathrm{O}$ emissions. With regard to $\mathrm{CH}_{4}$, the use of burners with greater burning efficiency, as well as the use of energy from this gas, could lessen the impact on the GW category. In addition, the $\mathrm{CH}_{4}$ dissolved in the effluent from the UASB reactors caused the TFs and the final effluent from the STP to become significant emission points. Emissions of $\mathrm{N}_{2} \mathrm{O}$ in the low-rate TFs contributed the most to the SOD category. Finally, it is recommended that future studies carry out environmental inventories of emissions in landfills that receive sewage sludge and in low-rate TFs, as a posttreatment step for anaerobic processes.

\section{ACKNOWLEDGMENT}

The authors would like to acknowledge the support obtained from the following Brazilian institutions: Coordenação de Aperfeiçoamento de Pessoal de Nível Superior-CAPES; Instituto Nacional de Ciência e Tecnologia em Estações Sustentáveis de Tratamento de Esgoto - INCT ETEs Sustentáveis and Companhia de Saneamento do Paraná - SANEPAR.

\section{REFERENCES}

AISSE, M. M. Tratamento de efluentes de reatores anaeróbios. 2002. Tese (Doutorado em Engenharia) - Escola Politécnica, Universidade de São Paulo, 2002.

ALMEIDA, P. G. S.; RIBEIRO, T. B.; SILVA, B. S.; AZEVEDO, L. S.; CHERNICHARO, C. A. L. Contribuição para o aprimoramento de projeto, construção e operação de reatores UASB aplicados ao tratamento de esgoto sanitário - Parte 6: Qualidade do efluente. Revista DAE, v. 66, p. 90-108, 2018. https://dx.doi.org/10.4322/dae.2018.043

AMARAL, K. G. C.; AISSE, M. M.; POSSETTI, G. R. C.; PRADO, M. R. Use of life cycle assessment to evaluate environmental impacts associated with the management of sludge and biogas. Water Science and Technology, v. 77, n. 9, p. 2292-2300, 2018. https://doi.org/10.2166/wst.2018.146

AMARAL, K. G. C.; AISSE, M. M.; POSSETTI, G. R. C. Avaliação da sustentabilidade no gerenciamento do lodo e biogás, em estação de tratamento de esgotos, utilizando a técnica de ACV. Revista Ambiente \& Água, v. 14, n. 5, 2019. http://dx.doi.org/10.4136/ambiagua. 2371

ANA (Brasil). Atlas esgotos: despoluição de bacias hidrográficas. Brasília, 2017.

ANDREOLI, C. V.; VON SPERLING, M.; FERNANDES, F. Lodo de esgotos: tratamento e disposição final. Belo Horizonte: UFMG, 2014.

APHA; AWWA; WEF. Standard Methods for the examination of water and wastewater. 22nd ed. Washington, 2012. $1496 \mathrm{p}$.

BITTENCOURT, S. Gestão do processo de uso agrícola de lodo de esgoto no estado do Paraná: aplicabilidade da resolução CONAMA 375/06. 190f. 2014. Tese (Doutorado em Engenharia de Recursos Hídricos e Ambiental) - Departamento de Hidráulica e Saneamento, Universidade Federal do Paraná, Curitiba, 2014. 
BITTENCOURT, S.; SERRAT, B. M.; AISSE, M. M.; GOMES, D. Sewage sludge usage in agriculture: a case study of its destination in the Curitiba Metropolitan Region, Paraná, Brazil. Water, Air, and Soil Pollution, v. 225, n. 2074, 2014. https://doi.org/10.1007/s11270-014-2074-y

BRESSANI-RIBEIRO, T.; BRANDT, E. M. F.; GUTIERREZ, K. G.; DÍAZ, C. A.; GARCIA, G. B.; CHERNICHARO, C. A. L. Potential of resource recovery in UASB/trickling filter systems treating domestic sewage in developing countries. Water Science and Technology, v. 75, n. 7, p. 1659-1666, 2017. https://doi.org/10.2166/wst.2017.038

CHERNICHARO, C. A. L.; RIBEIRO, T. B.; PEGORINI, E. S.; POSSETTI, G. R. C.; MIKI, M. K.; SOUZA, S. N. Contribuição para o aprimoramento de projeto, construção e operação de reatores UASB aplicados ao tratamento de esgoto sanitário - Parte 1: Tópicos de Interesse. Revista DAE, v. 66, p. 5-16, 2018. https://dx.doi.org/10.4322/dae.2018.038

CIESLIK, B. M.; NAMIESNIK, J.; KONIECZKA, P. Review of sewage sludge management: standards, regulations and analytical methods. Journal of Cleaner Production, v. 90, p. 1-15, 2015. https://doi.org/10.1016/j.jclepro.2014.11.031

CORRÊA, W. C.; AISSE, M. M. Avaliação do filtro biológico percolador de baixa taxa como pós tratamento de reatores de manto de lodo. In: SIMPÓSIO DO PROGRAMA DE PÓSGRADUAÇÃO EM ENGENHARIA DE RECURSOS HÍDRICOS E AMBIENTAL, 1., Curitiba, 2018. Anais[...] Curitiba: UFPR, 2019.

EL-FADEL, M.; MASSOUD, M. Methane emissions from wastewater management. Environmental Pollution, v. 114, n. 2, p. 177-185, 2001. https://doi.org/10.1016/S02697491(00)00222-0

FUCHS, V. J.; MIHELCIC, J. R.; GIERKE, J. S. Life cycle assessment of vertical and horizontal flow constructed wetlands for wastewater treatment considering nitrogen and carbon greenhouse gas emissions. Water Research, v. 45, n. 5, p. 2073-81, 2011. https://doi.org/10.1016/j.watres.2010.12.021

GUTIERREZ, K. G. Análise e gerenciamento de impactos ambientais no tratamento de esgoto doméstico mediante avaliação de ciclo de vida. 112 f. 2014. Tese (Doutorado em Saneamento, Meio Ambiente e Recursos Hídricos) - Escola de Engenharia, Universidade Federal de Minas Gerais, Belo Horizonte, 2014.

HERNANDEZ-PADILLA, F.; MARGNI, M.; NOYOLA, A.; GUERECA-HERNANDEZ, L.; BULLE, C. Assessing wastewater treatment in Latin America and the Caribbean: Enhancing life cycle assessment interpretation by regionalization and impact assessment sensibility. Journal of Cleaner Production, v. 142, p. 2140-2153, 2017. https://doi.org/10.1016/j.jclepro.2016.11.068

IPCC. Climate Change Synthesis Report. Contribution of Working Groups I, II and III to the Fifth Assessment Report of the Intergovernmental Panel on Climate Change. Geneva, 2014. $151 \mathrm{p}$.

KAMINSKI, G. F.; WAGNER; L. G.; SILVA, F. O. M.; POSSETTI, G. R. C. Análise crítica acerca da aplicação de queimadores enclausurados em ETEs para destruição de biogás. In: SIMPÓSIO MAUI BRASIL - ALEMANHA, 3., 2018, Curitiba. Anais[...] Curitiba: Universität Stuttgart; UFPR; SENAI; ABES-PR, 2018. 
KUMMER, L.; GONÇALVES, M. S.; MELO, Z.; EMIANI. A.; MELO, V. F.; GOMES, S. D. Individual and competitive adsorption of copper, zinc and lead in soils with contrasting texture. Journal of Experimental Agriculture International, v. 27, n. 1, p. 1-11, 2018. https://doi.org/10.9734/JEAI/2018/43891

LOBATO, L. C. S.; CHERNICHARO, C. A. L; SOUZA, C. L. Estimates of methane loss and energy recovery potential in anaerobic reactors treating domestic wastewater. Water $\begin{array}{llllllll}\text { Science } \& \text { Technology, } & \text { v. } 66, \quad \text { n. 12, }\end{array}$ https://doi.org/10.2166/wst.2012.514

LOBATO, L. C. S.; RIBEIRO, T. B.; SILVA, B. S.; FLÓREZ, C. A. D.; NEVES, P. N. P.; CHERNICHARO, C. A. L. Contribuição para o aprimoramento de projeto, construção e operação de reatores UASB aplicados ao tratamento de esgoto sanitário - Parte 3: Gerenciamento de lodo e escuma. Revista DAE, v. 66, p. 30-55, 2018. https://dx.doi.org/10.4322/dae.2018.040

LOPES, T. A. S.; QUEIROZ, L. M.; KIPERSTOK, A. Environmental performance of a fullscale wastewater treatment plant applying Life Cycle Assessment. Revista Ambiente \& Água, v. 13, n. 4, 2018. https://dx.doi.org/10.4136/ambi-agua.2216

METCALF \& EDDY INC. Wastewater engineering: Treatment and Reuse. 5. ed. New York: McGraw Hill, 2016.

MORAN, M. J.; SHAPIRO, H. N.; BOETTNER, D.D.; BAILEY M. B. Fundamentals of Engineering Thermodynamics. $7^{\text {th }}$ ed. New York: John Wiley \& Sons, 2010.

NEMECEK, T.; SCHNETZER, J. Methods of assessment of direct field emissions for LCIs of agricultural production systems. Zurich: ART, 2011.

NOYOLA, A.; PADILLA, A. R.; MORGAN, J. M. S.; GUERECA, L. P.; HERNANDEZ, F. P. Typology of Municipal Wastewater Treatment Technologies in Latin America. Clean - Soil, Air, Water, v. 40, n. 9, p. 926-932, 2012. https://doi.org/10.1002/clen.201100707

POSSETTI, G. R. C.; RIETOW, J. C.; COSTA, F. J. O. G.; WAGNER, L. G.; LOBATO, L. C. S.; RIBEIRO, T. B.; MELO, D. F.; REIS, J. A.; CHERNICHARO, C. A. L. Contribuição para o aprimoramento de projeto, construção e operação de reatores UASB aplicados ao tratamento de esgoto sanitário - Parte 5: Biogás e emissões fugitivas de metano. Revista DAE, v. 66, p. 73-89, 2018. https://dx.doi.org/10.4322/dae.2018.042

POSSETTI, G. R. C.; RIETOW, J. C.; CABRAL, C. B. G.; MOREIRA, H. C.; PLATZER, C.; BRESSANI-RIBEIRO, T.; CHERNICHARO, C. A. L. Energy recovery from biogas in UASB reactors treating sewage. Chapter 8. In: CHERNICHARO, C. A. L.; BRESSANIRIBEIRO, T. (Eds.). Anaerobic Reactors for Sewage Treatment: Design, Construction and Operation. London: IWA Publishing, 2019.

PROBIO 1.0. Programa de estimativa de produção de biogás em reatores UASB. Available at: site.sanepar.com.br/probio/probio.zip. Access: feb. 2021.

QUIROS, D. C.; SMITH, J.; THIRUVENGADAM, A.; HUAI, T.; HU, S. Greenhouse gas emissions from heavy-duty natural gas, hybrid, and conventional diesel on-road trucks during freight transport. Atmospheric Environment, v. 168, p. 36-45, 2017. https://doi.org/10.1016/j.atmosenv.2017.08.066

RAVISHANKARA, A. R.; DANIEL, J. S.; PORTMANN, R. W. Nitrous oxide (N2O): the dominant ozone-depleting substance emitted in the 21 st century. Science, v. 326, n. 5949 , 2009. https://dx.doi.org/10.1126/science.1176985 
SIMONS, A. Road transport: new life cycle inventories for fossil-fuelled passenger cars and non-exhaust emissions in ecoinvent v3. The International Journal of Life Cycle Assessment, v. 21, n. 9, p. 1299-1313, 2013. https://doi.org/10.1007/s11367-013-0642-9

SOUZA, C. L.; CHERNICHARO, C. A. L.; AQUINO, S. F. Quantification of dissolved methane in UASB reactors treating domestic wastewater under different operating conditions. Water Science \& Technology, v. 64, n. 11, 2011. https://doi.org/10.2166/wst.2011.695

USEPA. Environmental regulation and technology control of pathogens and vector attraction in sewage sludge. 40 CFR. Part 503. 625/R-92/013. Washington, 1992.

VASILAKI, V.; MASSARA, T. M.; STANCHEV, P.; FATONE, F.; KATSOU, E. A decade of nitrous oxide $\left(\mathrm{N}_{2} \mathrm{O}\right)$ monitoring in full-scale wastewater treatment processes: A critical $\begin{array}{llllll}\text { review. Water Research, v. 161, p. 392-412, } 2019 . & \text { v. }\end{array}$ https://doi.org/10.1016/j.watres.2019.04.022

VON SPERLING, M. Introdução à qualidade das águas e ao tratamento de esgoto. 4. ed. Belo Horizonte: UFMG, 2014.

YOSHIDA, H.; TEN HOEVE, M.; CHRISTENSEN, T. H.; BRUUN, S.; JENSEN, L. S.; SCHEUTZ, C. Life cycle assessment of sewage sludge management options including long-term impacts after land application. Journal of Cleaner Production, v. 174, p. 538547, 2018. https://doi.org/10.1016/j.jclepro.2017.10.175 